\title{
A AIDS no Brasil: uma epidemia em mutação
}

A epidemia de AIDS completa, neste ano de 2000, sua segunda década. Caracterizada segundo uma dinâmica de contínua transformação, vem atingindo mais de perto novos segmentos populacionais - e, de forma crescente, estratos sociais menos favorecidos -, além de estar chegando a cidades onde, até então, sua presença não havia sido registrada. Cabe a nós, profissionais de Saúde Pública, monitorar e analisar de forma ininterrupta essas modificações, de modo a auscultar as novas tendências da epidemia, rever estimativas e propor estratégias preventivas, a um só tempo, éticas, pragmáticas e culturalmente apropriadas.

A atual epidemia com que nos defrontamos é bastante complexa, resultante da existência de subepidemias regionais ou definidas conforme a natureza das diferentes interações sociais. Cabe, portanto, avaliá-la sob perspectivas diversas e complementares, renovando e refinando permanentemente seus instrumentos de análise e arcabouço conceitual.

Em razão das inúmeras e profundas mutações nos estádios evolutivos da infecção pelo HIV, o exame detalhado das tendências da epidemia deve combinar obrigatoriamente dados provenientes dos casos de AIDS já registrados - um retrato consolidado do passado - com aqueles derivados da investigação da ocorrência de novas infecções. A análise integrada das notificações da doença em diferentes períodos e das condições de sua manifestação serve tanto para as populações sob maior risco de exposição ao HIV quanto à população geral, indiscutivelmente mais vulnerável hoje do que nos primórdios da epidemia.

Cabe, igualmente, ampliar as tradicionais categorias de análise, incorporando ao moderno conhecimento epidemiológico os aportes provenientes da Sociologia e da Antropologia, do desenvolvimento dos métodos quantitativos e, ainda, do entrecruzamento das distintas abordagens, exemplificadas no presente volume mediante a aplicação dos métodos de análise das redes sociais mais recentes.

Diante de tais desafios, Cadernos deSaúde Pública reúne especialistas que há muito vêm estudando a questão sob ópticas as mais diversas, para apresentar seus trabal hos neste número especialmente dedicado à epidemia da AIDS no Brasil.

Como constatará o leitor, trata-se de contribuição atualizada, abrangendo desde questões teóricas e metodológicas a achados até então inéditos, que enriquecerá, sem dúvida, a nossa literatura científico-técnica dedicada ao tema.

Cabe observar que alguns dos artigos aqui publicados foram veiculados preliminarmente através de brochura de circulação restrita, editada pela Coordenação Nacional de DST e AIDS do Ministério da Saúde. A mesma foi distribuída a participantes do 3o Congresso Brasileiro de Prevenção em DST e AIDS, realizado em dezembro de 1999, no Rio de Janeiro, visando subsidiar mesa-redonda sobre a pauperização da AIDS no Brasil.

Não nos permitimos maiores delongas para não privar o leitor da fruição imediata deste conjunto de artigos. Esperamos que esta sirva de inspiração para que as unidades de saúde, escolas, organizações governamentais e não-governamentais preocupadas com o bem-estar da coletividade e a promoção social desenvolvam novas propostas e programas voltados à prevenção e ao tratamento das pessoas vivendo com HIV e AIDS.

A dimensão e a gravidade do desafio imposto pela epidemia em nosso País exigenos permanente fôlego e renovada disposição para enfrentá-la com as armas da ciência e da solidariedade.

Eucl ides Ayres de Castilho

Coordenação Nacional de DST e AIDS do Ministério da Saúde Departamento de Informações em Saúde/CICT Fundação Oswaldo Cruz

Célia Landmann Scwarcwald

Departamento de Informações em Saúde/CICT

Fundação Oswaldo Cruz
Francisco Inácio Bastos

Departamento de Informações em Saúde/CICT

Fundação Oswaldo Cruz

Maria Goretti M. Fonseca

Coordenação Nacional de DST eAIDS do Ministério da Saúde 


\section{AIDS in Brazil: a changing epidemic}

This year, 2000, the AIDS epidemic completes its second decade. Characterized by constantly changing dynamics, the epidemic has reached new population groups and cities where it had not been recorded previously, in addition to increasingly affecting the country's less privileged social segments. As health professionals, our duty is to constantly monitor and analyze such changes, auscultating the epidemic's new trends, revising old estimates, and proposing ethical, pragmatic, and culturally appropriate preventive strategies.

The current epidemic is highly complex, resulting from regional sub-epidemics and those defined according to various types of social interaction. It is thus crucial to evaluate the epidemic from various and complementary perspectives, constantly renewing and refining our analytical tools and conceptual framework.

Given the numerous and profound changes in the evolutionary stages of HIV infection, any analysis of the epidemic's trends must combine data from reported AIDS cases (a consolidated portrait of the past) with those based on new infections. Integrated analysis of AIDS reporting during different periods and under different conditions serves both for the population groups at greatest risk of exposure to HIV and the overall population, unquestionably more vulnerable today than at the beginning of the epidemic.

It is equally important to expand traditional analytical categories, incorporating the contributions of sociology and anthropology, the development of quantitative methods, and the cross-analysis of these various approaches into modern epidemiological knowledge, as exemplified in the current volume by the application of modern techniques in social network analysis.

Rising to such challenges, Cadernos de Saúde Pública has invited a group of experts with a variety of approaches to present their work in this issue focusing specifically on the AIDS epidemic in Brazil.

Readers will find this an up-to-date contribution encompassing theoretical and methodological questions and previously unpublished findings which will doubtless enrich the specialized scientific literature.

It should be noted that some of the papers published here were previously disseminated in a brochure with restricted circulation, edited by the National Coordination of STD and AIDS of the Ministry of Health. The same brochure was distributed, as a contribution to the work of the round table on the "pauperization" of AIDS in Brazil, to some of the participants in the III Brazilian Meeting on STD and AIDS Prevention, which took place in December, 1999, in Rio de Janeiro.

In order to allow readers to take immediate advantage of this set of articles, we invite them to begin what we are sure will be a fruitful perusal. We hope it will serve as an inspiration for public health clinics, schools, government agencies, and nongovernmental organizations concerned with the collective well-being, social promotion, and the development of new proposals and programs for both prevention and the treatment of people living with HIV and AIDS.

The scope and severity of the challenge raised by the epidemic in our country demands constant stamina and renewed courage to face it with the arms of science and solidarity.

\section{Euclides Ayres de Castilho}

Coordenação Nacional de DST eAIDS do Ministério da Saúde Departamento de Informações em Saúde/CICT Fundação Oswaldo Cruz

Célia Landmann Scwarcwald

Departamento de Informações em Saúde/CICT Fundação Oswaldo Cruz

\section{Francisco Inácio Bastos}

Departamento de Informações em Saúde/CICT

Fundação Oswaldo Cruz

Maria Goretti M. Fonseca

Coordenação Nacional de DST e AIDS do Ministério da Saúde 